This is an electronic reprint of the original article. This reprint may differ from the original in pagination and typographic detail.

Author(s): Töytäri, Aija; Tynjälä, Päivi; Piirainen, Arja; Ilves, Vesa

Title: $\quad$ Higher education teachers' descriptions of their own learning : a quantitative perspective

Year: $\quad 2017$

Version:

Please cite the original version:

Töytäri, A., Tynjälä, P., Piirainen, A., \& Ilves, V. (2017). Higher education teachers' descriptions of their own learning : a quantitative perspective. Higher Education Research and Development, 36(6), 1295-1304.

https://doi.org/10.1080/07294360.2017.1303455

All material supplied via JYX is protected by copyright and other intellectual property rights, and duplication or sale of all or part of any of the repository collections is not permitted, except that material may be duplicated by you for your research use or educational purposes in electronic or print form. You must obtain permission for any other use. Electronic or print copies may not be offered, whether for sale or otherwise to anyone who is not an authorised user. 


\title{
Higher Education Teachers' Descriptions of Their Own Learning: A Quantitative Perspective
}

\author{
Aija Töytäri, Päivi Tynjälä, Arja Piirainen \& Vesa Ilves
}

\begin{abstract}
In this large-scale study, higher education teachers' $(n=1028)$ descriptions of their own learning are examined with quantitative analyses. The study follows up an earlier qualitative study that, using a phenomenographic approach, identified four different ways in which teachers at Finnish universities of applied sciences described their own learning. The purpose of the present study was to find out how teachers' descriptions were divided into the categories formed in the previous study and to examine whether teachers' descriptions of their learning differ according to their position, gender and age. The results show that most teachers described their learning as an individual activity. Differences between teacher, gender and age groups were found. Lecturers were represented more often than senior lecturers in the category of individual learning, and male teachers more often than their female colleagues. Individualistic learning was especially typical of lecturers under 50 years of age.
\end{abstract}

Keywords: descriptions of learning, quantitative research, higher education teachers, university of applied sciences

\section{Introduction}

Because of rapid changes in society, world of work, technology and pedagogical knowledge, teachers' learning and professional development have become more important than ever. The purpose of the present study is to examine higher education teachers' views on their own learning and whether there are differences between different groups of teachers in how they describe their learning.

Today's world is characterised by rapid changes in all areas of life and society. This is also reflected in significant transformations in the world of work and professions, creating ehallenges in higher education as well. The fast increase of information has made finding, analysing and utilising relevant knowledge easier but also more demanding than ever in terms of reliability and validity. Digitalisation offers new possibilities for the acquisition of knowledge, but, at the same time, it changes the nature of work as well as teaching and learning practices..

In many countries, fast societal change has led to higher education being divided into two parallel sectors: traditional scientific universities and more practically oriented universities of applied sciences. The aim of the universities of applied sciences is to develop partnerships with industry and commerce and to offer education involving more work experience than the traditional universities do. For teachers, this means they need to have the ability to 
collaborate with partners outside the academy, as well as the competence to utilise and develop new kinds of pedagogical solutions. Thus, teachers' role has changed from being a transmitter of knowledge in classrooms to being an actor who supports students' learning with modern technology and collaborates in national and international networks. As a result of these changes, the role of professional development and learning has become emphasised in teachers' work.

While there is an increasing body of knowledge related to higher education teachers' conceptions of learning (e.g., Darling-Hammond \& Brandsford, 2007; van Eekelen, Boshuizen, \& Vermunt, 2005) and approaches to teaching (e.g., Elen \& Lindblom-Ylänne, 2007; Hativa, 2000; Lindblom-Ylänne \& Nevgi, 2011), less is known about how higher education teachers themselves learn. An exception is a large-scale qualitative study on Finnish universities of applied sciences (`Author, 2016` [details removed for peer review]), where four different ways of how teachers described their own learning were identified. In the present study, we use the same data to examine the distribution of teachers into the four categories and possible differences between the different teacher groups. At Finnish universities of applied sciences, there are senior lecturers and lecturers. The former are required to have a Doctorate or Licentiate degree, while the latter need at least a Master's degree level education. In addition, both need to have at least three years of work experience in their own professional field and 60 points worth of pedagogical education. Lecturers' work consists of teaching in their own subject as well as conducting research and development $(\mathrm{R} \& \mathrm{D})$ related to their field. In addition to teaching and $\mathrm{R} \& \mathrm{D}$, the senior lecturers are responsible for the development of study programmes in their field. Senior lecturers also have responsibility for the national and international development of their field in higher education, research and development. One purpose of our study was to examine whether these different educational backgrounds and working profiles of lecturers and senior lecturers are reflected in how they describe their own learning.

\section{Studies on higher education teachers' work and learning}

During the last few decades, higher education researchers have begun to pay more and more attention to university pedagogy and teachers' work. For example, teachers' conceptions of learning (e.g., Darling-Hammond, 2000; Darling-Hammond et al., 2007; van Eekelen et al., 2005), teaching (Elen et al., 2007; Hativa, 2000; Lindblom-Ylänne et al., 2011; Postareff \& Lindblom-Ylänne, 2008), and broader approaches to teaching —involving both conceptions, strategy and practice — have been widely studied (Kember, 1997; Kember \& Kwan, 2000; Parpala, 2007). In many studies, two basic approaches to teaching have been identified: 1) the teacher-centred or content-oriented approach emphasising one-way knowledge transmission from the teacher to the students, and 2) the student-centred or learning-oriented approach focusing on supporting student learning (Kember, 1997; Prosser \& Trigwell, 1999; Postareff et al., 2008). In some studies, differences between disciplines have been found when comparing teachers' teaching approaches (e.g., Lindblom-Ylänne, Trigwell, Nevgi, \& Ashwin, 2006; Stes \& Petegem, 2014). 
In her phenomenographic studies, Åkerlind (2003, 2011) has found out that academics' experiences of their development as teachers resemble the approaches to teaching described above. She identified three different ways as to how teachers perceived their professional development: 1) teacher comfort - professional growth meant that the teachers felt more confident and needed to put less effort into teaching; 2) teaching practice - development of the teaching practice focused on diversifying teaching methods; and 3) student learning professional development means improving student learning. In another study, Åkerlind (2004) examined teachers' experiences and understanding of what it means to be a higher education teacher, that is, teachers' experience of being a teacher rather than just engaging in teaching. The teachers' understanding and experiences varied from teacher transmission and teacher-student relations to student engagement and student learning in terms of development themes. These findings show that teachers' conceptions of teaching and student learning as well as their interrelation play a central role in how teachers experience their work. Therefore, the authors of the present study emphasize that it is important to investigate not only teachers' conceptions of teaching and learning and the relationship between these, but also teachers' development and role (Åkerlind, 2008, 2007, 2004). Already in the 1990s, Trigwell and Prosser (1996; Prosser \& Trigwell, 1997) stated that teachers' continuing education should focus on the conceptual understanding of teaching and learning rather than solely on teaching methods. More recently, in many countries, teacher development programmes for university teachers have evolved with this focus in mind (e.g., Gibbs \& Coffey, 2004; Stes \& Petegem, 2011).

Although higher education teachers' conceptions of learning and teaching in general have been widely studied, there is less research on how teachers' experience or perceive their own learning. Åkerlind's $(2003,2007)$ studies on teachers' growing and developing as a teacher come close to this topic, but their focus was on teachers' broader professional development rather than on teachers' conceptions of their own learning. To the best of our knowledge, a recent study at the Finnish universities of applied sciences ('Author, 2016 [details removed for peer review]) is the only previous study to have focused on teachers' understanding of their own ways of learning. The study was exceptional for a qualitative study as the data were unusually large, with more than 1,600 participants. In that study, four categories of teachers' descriptions of their own learning were determined: 1) individual learning, 2) collegial learning, 3) team learning, and 4) innovative partnership learning.

In the first category, individual learning, the teachers described their learning as intrapersonal cognitive activity. This view reflected the traditional, individualistic conception of learning. The approach to knowledge construction was described in terms of acquisition and doing, and the nature of reflection was individual. In learning situations, teachers used written or audiovisual material. The source of motivation for learning came from external pressures or an internal desire for self-development. The second category, collegial learning, differed from the first one in that teachers described their learning as collegial activity. In other words, teachers described their learning as taking place in collaboration with another person, usually a colleague in the same field. Knowledge construction and reflection were described in terms of interactive learning. The learning situations were interactive encounters, and, similar to the 
first category, the motivation to learn was due to external pressure or an internal interest in self-development. In the third category, team learning, teachers' descriptions of their learning focused more on sharing skills and knowledge through active collaboration and teamwork with others in their own education field and with workplace partners. The knowledge construction was based on collaboration and participation in a group and the nature of reflection was interactive, taking place in a group. Teachers learned to solve collaborative problems, and the motivation to learn came from the need to learn together. Finally, the fourth category, innovative partnership learning, reflects teachers' experiences where learning extends to the level of a community and to the activity of innovation. This form of knowledge construction was described as co-creational and innovative. Similarly, the nature of reflection was collective and creative, and social networks were mentioned regarding typical learning situations. The motivation was based on the desire to develop something new together. In this category, teachers' learning was associated with tasks related to regional and societal development. Teachers emphasized learning in collaboration with workplace representatives and international partners. The widening of the individualistic learning horizon to workplaces, broader society and international colleagues represents the broadest understanding of professional learning identified in the study, and the authors concluded that this view of learning is in line with the mission of universities of applied sciences ( Author, 2016 ' [details removed for peer review]).

While the above reviewed study on Finnish higher education teachers' descriptions of their own learning and other previous studies on teachers' conceptions of learning have mainly followed the qualitative approach, there are no large-scale studies on the prevalence of different conceptions or on how different conceptions are distributed among different groups of higher education teachers. These are the issues the present study tackles in the context of universities of applied sciences, using the data of the study by Author and colleagues (2016).

\section{Aim of the study}

The aim of the present study was to examine the prevalence of different kinds of descriptions of higher education teachers' own learning. Specifically, the following research questions were addressed:

1. How are teachers divided into the four categories of learning descriptions?

2. How do teachers' descriptions of their own learning differ between the four categories when compared as senior lecturers vs lecturers?

3. How do teachers' descriptions of their own learning differ between the four categories when compared by gender and age?'

\section{Research method}

\section{Data collection}

The data of the study were collected from teachers working at Finnish universities of applied sciences. The Finnish system of higher education is comprised of traditional universities and 
universities of applied sciences. The latter were established in the early 1990s in response to the needs of the labor market and to provide a more business-oriented higher education (for more details, see Ministry of Education 2016).

The present study was part of a larger research project related to teachers' professional development at Finnish universities of applied sciences. A link to a structured questionnaire was sent by e mail to 5,960 teachers. A total of 1,622 teachers (27\%) responded. The data of the present study are based on the open-ended question: "How do you learn, yourself?" There was no word limit for writing the answer. A total of 1,028 responses were accepted for the study, excluding 594 blanks or one-word answers.

The present study was part of a larger research project in which a structured questionnaire about teachers' work and learning was sent to 5,960 teachers at universities of applied sciences in Finland. The questionnaire consisted of 25 questions. The first set of questions focussed on teachers ' background variables, such as sex, age, educational background, experience, and pedagogical training. The second part of the questionnaire included questions about teacher's work, competencies and professional development. The other parts dealt with succeeding as a teacher at university of applied sciences, support teachers had received for their professional development, and their ideas of the future of teacher's profession and teaching. .

The questionnaire was sent by e-mail and a total of 1,622 (27\%) teachers responded. The data of the present study are based on the open-ended question which was situated in the second part of the questionnaire dealing with teachers work and competences: "How do you learn yourself?" There were no space limits for writing the answer and no definitions about learning. Thus, teachers themselves could determine how they defined learning and what they understood by learning. Altogether 1,059 responses were accepted for the study, excluding 563 blanks or one-word answers. The range in the number of the words was $2-133$. In total, the data included 17,003 words (50 pages of text; , written as sentences).

Data analysis

The data were first analysed qualitatively with the phenomenographic method, which produced the four different categories of teachers' descriptions of their own learning as outlined above. ). The phenomenographic analysis is described in detail elsewhere (Authors, 2016.)

For the present study, every answer was numerically coded by two researchers into one of the four hierarchical categories. In the classification, the following scale was used. 1) Individual learning (teacher mentioned only her/himself as an actor in learning situations), 2) Collegial learning (teacher mentioned some other person with whom she/he acted in learning situations), 3) Team learning (teacher acted and reflected in a team of colleagues, in a social 
context, but only within her/his own field), and 4) Innovative partnership learning (teacher described learning as researching and developing work in interaction, in networks of colleagues, students and stakeholders, also internationally). Based on phenomenographic principles, this system of categories can be seen as hierarchical, where category 1 represents the narrowest description of the teacher's own learning and category 4 represents the broadest description. Therefore, in cases where the answer represented more than one category, it was assigned to the broadest of these. Two researchers read and coded all of the answers, first alone. After that, the researchers discussed their codings and pursued consensus on the problematic cases. When a consensus on all of the codings was reached, frequencies and percentages of the answers were counted for every category, and then compared as groupings into senior lecturers vs lecturers and also by age and gender.

\section{Results}

Table 1 shows the distribution of teachers across the categories of learning descriptions. The total number of answers was 1,028 . Over half of all respondents $(53 \%)$ belonged to category 1 , individual learning. Less than one-third of the teachers described their learning as collegial learning, and a little over $10 \%$ as team learning. $5 \%$ belonged to category 4 , innovative partnership learning.

Table 1. Distribution of Teachers into the Four Categories of Learning Descriptions

\begin{tabular}{|l|l|l|}
\hline Categories & $N$ & $\%$ \\
\hline Individual learning & 546 & 53 \\
\hline Collegial learning & 301 & 29 \\
\hline Team learning & 135 & 13 \\
\hline Innovative partnership learning & 46 & 5 \\
\hline Total & $\mathbf{1 0 2 8}$ & $\mathbf{1 0 0}$ \\
\hline
\end{tabular}

The distribution of teachers into the four categories according to different teacher groups, senior lecturers and lecturers, is presented in Table 2. More than $40 \%$ of senior lecturers and over $50 \%$ of lecturers belonged to the first category, Individual Learning. Over one-third $(35 \%)$ of senior lecturers and under one-third $(28 \%)$ of lecturers belonged to the category Collegial Learning. $16 \%$ of the senior lecturers and $12 \%$ of the lecturers described their learning as a Team Activity (category 3), whereas in the Innovative Partnership Learning category (category 4) $6 \%$ were senior lecturers and $4 \%$ lecturers. The chi-square test shows that the differences between the teacher groups are statistically significant (chi-square $=$ $13.42, d f=3 ; p=0.0038)$.

Table 2. Distribution of Teachers into Four Categories by Teacher Group

\begin{tabular}{|l|l|l|l|l|l|l|}
\hline Categories & \multicolumn{2}{l|l|}{$\begin{array}{l}\text { Senior } \\
\text { lecturers }\end{array}$} & \multicolumn{2}{l|}{ Lecturers } & \multicolumn{2}{l|}{ All } \\
\hline & $N$ & $\%$ & $N$ & $\%$ & $N$ & $\%$ \\
\hline Individual learning & 84 & 42 & 462 & 56 & 546 & 53 \\
\hline
\end{tabular}




\begin{tabular}{|l|l|l|l|l|l|l|}
\hline Collegial learning & 71 & 35 & 230 & 28 & 301 & 29 \\
\hline Team learning & 33 & 16 & 102 & 12 & 135 & 13 \\
\hline Innovative partnership learning & 13 & 6 & 33 & 4 & 46 & 4 \\
\hline Total & 201 & 100 & 827 & 100 & 1028 & 100 \\
\hline $\begin{array}{l}\text { chi-square test }=13,42 \\
d f=3 \\
p=0.0038\end{array}$ & \multicolumn{5}{|l|}{} \\
\hline
\end{tabular}

Table 3 shows the distribution of categories by gender in the two teacher groups. One-third of female and over $50 \%$ of male senior lecturers described their learning in terms of Individual Activity, that is, category 1, while almost half of the female and almost more than $70 \%$ of the male lecturers belonged to this category. Collegial Learning, category 2, was more typical to female teachers, regarding both senior lecturers and lecturers. Similarly, female teachers in both teacher groups reported relatively more often that their learning can be described as Team Learning. Relatively more male senior lecturers and female lecturers belonged to the category of Innovative Partnership Learning, category 4, but here the frequencies were very small in both teacher groups and genders. The chi-square test shows that the differences between the gender groups are significant.

Table 3. Distribution of Categories by Gender in Two Teacher Groups

\begin{tabular}{|c|c|c|c|c|c|c|c|c|c|c|}
\hline \multirow[t]{3}{*}{ Categories } & \multicolumn{4}{|c|}{ Senior lecturers } & \multicolumn{4}{|c|}{ Lecturers } & \multicolumn{2}{|l|}{ All } \\
\hline & \multicolumn{2}{|c|}{ Female } & \multicolumn{2}{|c|}{ Male } & \multicolumn{2}{|c|}{ Female } & \multicolumn{2}{|c|}{ Male } & \multirow{2}{*}{$N$} & \multirow[b]{2}{*}{$\%$} \\
\hline & $N$ & $\%$ & $N$ & $\%$ & $N$ & $\%$ & $N$ & $\%$ & & \\
\hline Individual learning & 33 & 33 & 51 & 51 & 294 & 49 & 164 & 74 & 542 & 53 \\
\hline Collegial learning & 45 & 45 & 26 & 26 & 192 & 32 & 34 & 15 & 297 & 29 \\
\hline Team Learning & 18 & 18 & 15 & 15 & 84 & 14 & 18 & 8 & 135 & 13 \\
\hline $\begin{array}{l}\text { Innovative partnership } \\
\text { learning }\end{array}$ & 5 & 5 & 8 & 8 & 26 & 4 & 7 & 3 & 46 & 5 \\
\hline Total & 101 & 100 & 100 & 100 & 596 & 100 & 223 & 100 & 1020 & 100 \\
\hline $\begin{array}{l}N=1028 \\
\text { Missing data }=8\end{array}$ & $\begin{array}{l}\text { chi- } \\
d f= \\
p=\end{array}$ & $\begin{array}{l}\text { re tes } \\
94\end{array}$ & & & $\begin{array}{l}\text { chi-s } \\
d f= \\
p=0\end{array}$ & re tes & 39,2 & & & \\
\hline
\end{tabular}

The distribution of categories by age in the two teacher groups is shown in Table 4.

Individual learning was most typical among lecturers under 50 years old, of whom more than $60 \%$ belonged to this category. Of senior lecturers of the same age, $38 \%$ belonged to the Individual Learning category. $44 \%$ of senior lecturers older than 50 years described their learning in terms of individual activity, while the respective portion of lecturers was $50 \%$. Thus, individual learning was more typical of senior lecturers who were older teachers, while in lecturers it was more typical among teachers younger than 50 years.

Of younger senior lecturers, $43 \%$ belonged to the category of Collegial Learning, while there were less younger lecturers $(27 \%)$ belonging to this category. About one-third (31\%) of older 
senior lecturers described their learning as collegial, and there was almost the same proportion (29\%) of older lecturers in this category.

Team learning was a little more typical among older lecturers than among young ones; $15 \%$ of the older lecturers and $9 \%$ of the young ones described their learning in terms of team learning. In the Innovative Partnership Learning category, there were five percent of lecturers older than 50 years and two percent of younger lecturers. The chi-square test showed that the differences between the age groups were significant only in the lecturer group. When the four categories were recoded into two categories on the basis of individual vs social forms of learning (category 1 belonging to individual, and categories 2-4 to social forms), the age differences became a little clearer, that is, of the senior lecturers under 50 years of age more teachers (61\%) described their learning as social activity compared to those who were older than 50 years $(56 \%)$. Among the lecturers, the proportions were the opposite, that is, social forms of learning were mentioned more often by older teachers (49\%) than by younger ones $(38 \%)$.

Table 4. Distribution of Categories by Age in Two Teacher Groups

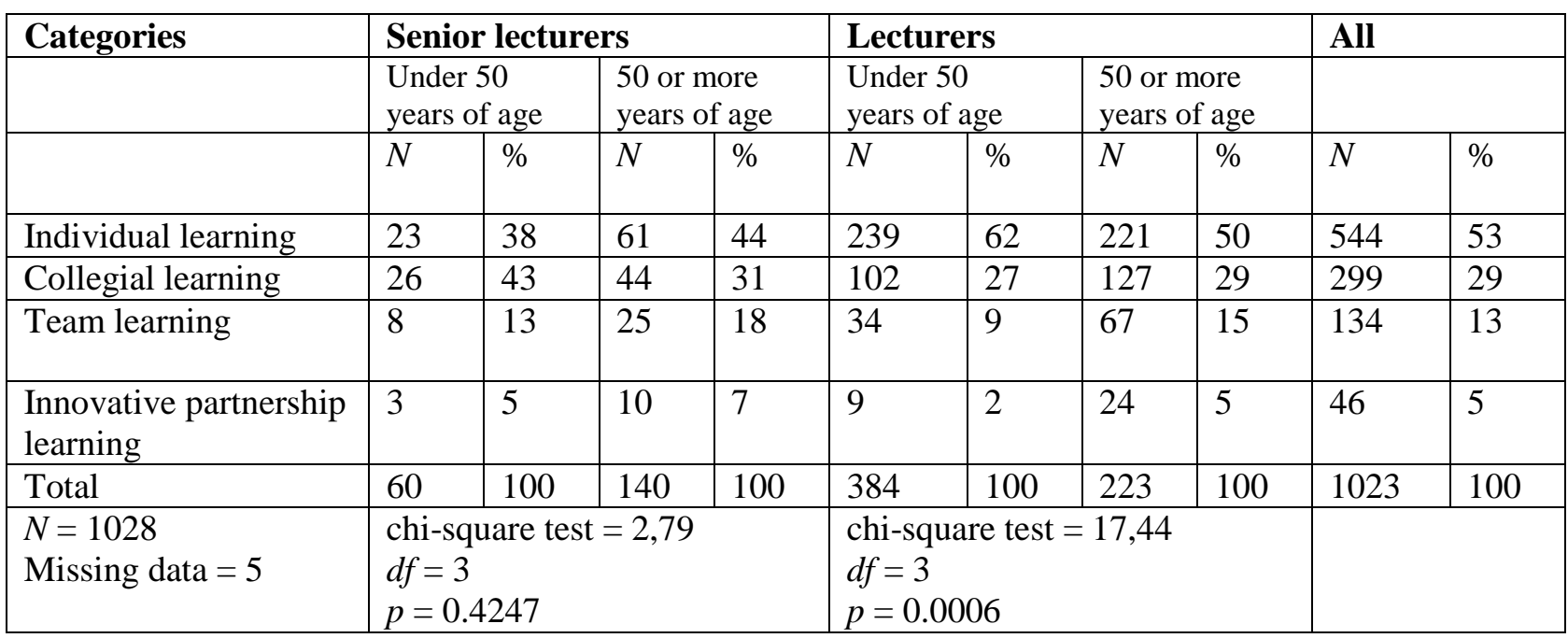

\section{Discussion}

The main result of this study is that most teachers at Finnish universities of applied sciences described their own learning as an individual activity. This finding is quite unexpected since, according to some recent studies (Mäki, 2012; Savonmäki, 2007), these teachers' tasks and role should have changed from that of an individual transmitter of knowledge in classrooms to an actor who supports students' learning also in workplaces and whose work involves regional development activities and collaboration within national and international networks. About 13 percent of all teachers described their learning as taking place in teams, and five percent mentioned partnerships and networks in this regard. Thus, only a very small group of teachers saw their learning as an innovative activity with partners outside the university. As the main point of universities of applied sciences is to develop work and regional collaboration around their university, it is alarming that teachers seldom mentioned these tasks as involving learning. The reason for this discrepancy may lie in the traditional 
conceptions of learning. It may be that teachers are widely involved in different kinds of collaborative activities but only a few of them associate those activities with learning. This, in turn, may be due to the fact that much of the learning taking place at work is informal and unintentional in nature (e.g., Eraut, 2004; `Author, 2008` [details removed for peer review]; 'Author, 2013` [details removed for peer review]).

There were differences between different teacher groups in how they described their learning. Lecturers were represented more often than senior lecturers in the category of Individual Learning, and male teachers more often than their female colleagues. In the categories referring to more sophisticated or diverse forms of learning, female teachers were more often represented than their male colleagues. . The findings show that the experience of learning as interaction and knowledge sharing is more common among teachers with a higher educational background and among female teachers.

The findings about sex differences are interesting. While two thirds of women with higher educational background are collegial in their learning, half of men with same level of education show preference for individualistic learning. An interpretation of thismight be that it is more typical for women than for men to share things together and with more education they get courage to do that. However, it should be noticed that both for male and female respondents, the portion of those expressing collaborative forms of learning was bigger in the group of senior lecturers than among lecturers. Thus, educational background makes a difference in both sexes. .

The results related to the differences between the age groups are a little more difficult to interpret, but in general it can be said that especially lecturers, as well as senior lecturers 50 or more years old, were characterised by individualistic learning more than other teachers. Among the lecturers, there was also a clear difference between younger and older teachers in regard to team learning, which was more common among the older teachers, and the same trend could also be seen with regard to senior lecturers. Altogether, individualistic learning was especially typical of lecturers under 50 years of age. Thus, it seems that teachers' position and their educational level (in this case, senior lecturers with a Doctoral degree) explain better than does their age how teachers describe their learning.

Altogether, the results profile a big portion of teachers at Finnish universities of applied sciences as being individualistic learners. However, female senior lecturers proved to be an exceptional group, since almost $70 \%$ of these teachers described their learning in terms of collegial, team and innovative partnership learning. The most surprising finding was the small number of teachers belonging to the innovative partnership learning category. It seems that many teachers don't use networks for their own learning, or they do not recognize learning taking place in informal settings and collaborative partnerships.

Methodologically, this research is unique. To the best of our knowledge, there are no other studies where large qualitative questionnaire data were first analysed with the phenomenographic method and then quantified for statistical analysis (for an example with small data, see Paakkari, Tynjälä, Torppa, Villberg, \& Kannas, 2015). Usually, 
phenomenographic studies are based on interview data, which limits the number of participants.

A limitation of this study is that the participating teachers wrote fairly short answers to the survey questions concerning their own learning. Despite this, the principles of phenomenographic data analysis could be applied since most of the written answers were lucid and variation among the responses was easily discernible. Another limitation concerns the generalisation of the findings. This study was conducted at Finnish universities of applied sciences, and it can be speculated whether the results can be generalised to other countries. Therefore, it would be of interest to study teachers' experiences of their own learning in other countries with a similar dual system of higher education as in Finland, that is, what equates to traditional universities and universities of applied sciences.

The practical implications of the present study are twofold. First, it shows that more than half of the teachers had a traditional conception of learning as an individualistic cognitive activity. Therefore, it is important that teachers' continuing education focuses also on teachers' conceptual understanding of teaching and learning rather than just on teaching methods (see, e.g., Trigwell \& Prosser, 1996; Prosser \& Trigwell, 1997). Developing teachers' learning conceptions in the direction of social activity would probably promote their working with students, colleagues, stakeholders or other specialists outside their university. Diverse, multidirectional interaction is also likely to diversify the ways of handling knowledge, yielding new ways to understand the versatility of phenomena and improving the quality of learning.

Second, the findings of our study raise the question about the alignment of teachers' learning, work practices and the tasks, strategies and goals of universities of applied sciences.

Teachers' descriptions of their learning at their workplace, or rather lack of it, do not appear to align with the suggested new profile of teaching in higher education (Hämäläinen \& De Wever, 2013). Networking and partnerships between education and work are nowadays seen as important contributing factors to innovation and competence development (e.g., Billett, Ovens, Clemans, \& Seddon, 2007; `Author, 2013 [details removed for peer review]; `Author, 2014 [details removed for peer review]). This kind of thinking was present in the fourth category. However, only few of the teachers in this study described their learning along these lines. Thus, it seems that there is a need for augmenting teacher development programmes at universities of applied sciences with modern developmental work.

\section{References}

Åkerlind, G. S. (2003). Growing and developing as a university teacher: Variation in meaning. Studies in Higher Education, 28(4), 375-390.

\section{Akerlind, G. S. (2004). A new dimension to understanding university teaching. Teaching in Higher Eduen, $9(3), 363-375$.}

Åkerlind, G. S. (2007). Constraints on academics' potential for developing as a teacher Variation in meaning. Studies in Higher Education, 32(1), 21-37. 
Akerlind, G. S. (2008b). A phenomenographic approach to developing academics' understanding of the nature of teaching and learning. Teaching in Higher Education, 13(6), $633-644$.

Akerlind, G. S. (2011). Separating the 'teaching' from the 'academic': Possible unintended consequences, Teaching in Higher Education, 16(2), $183-195$.

`Author, 2008` [details removed for peer review]

`Author, 2013` [details removed for peer review]

`Author, 2014` [details removed for peer review]

`Author, 2016` [details removed for peer review]

Billett, S., Ovens, C., Clemans, A., \& Seddon, T. (2007). Collaborative working and contested practices. Forming, developing and sustaining social partnerships in education. Journal of Education Policy, 22(6), 637-656.

Đarling-Hammond, L. (2000). Teacher quality and student achievement: $\Lambda$ review of state policy evidence. Education Policy Analysis Archives, 8(1), 144.

Darling-Hammond, L., \& Bransford, J. (Eds.) (2007). Preparing teachers for a changing world: What teachers should learn and be able to do. San Francisco, CA: Jossey-Bass.

Elen, J., \& Lindblom-Ylänne, S. (2007). Faculty development in research-intensive universities: The role of academics' conceptions on the relationship between research and teaching. International Journal for Academic Development, 12(2), 123-139.

Eraut, M. (2004). Informal learning at work. Studies in Continuing Education, 26(3).

Gibbs, G., Coffey, M. (2004). The impact of training of university teachers on their teaching skills, their approach to teaching and the approach to learning of their students Active Eearning in Higher Education, 5(1), $87-100$.

Hativa, N. (2000). Teacher thinking, beliefs, and knowledge in higher education: An introduction. Introductional Science, 28(5), 331-334.

Hämäläinen, R., \& De Wever, B. (2013). Vocational education approach: New TEL settings - New prospects for teachers' instructional activities? Computer-Supported Collaborative Learning, 8(3), 271-291.

Kember, D. (1997). A reconceptualization of the research into university academies' eonceptions of teaching. Learning and Instruction, 7(3), 255-275.

Kember, D., \& Kwan, K. P. (2000). Lecturers' approaches to teaching and their relationship to conceptions of good teaching. Instructional Science, 28(5), 469-490. 
Lindblom-Ylänne, S., \& Nevgi, A. (2011). Regulation of university teaching. Instructional Science, 39(4), 483-495.

Lindblom Ylänne, S., Trigwell, K., Nevgi, A., \& Ashwin, P. (2006). How approaches to teaching are affected by discipline and teaching context. Studies in Higher Education, 31(3), 285298.

Mäki, K. (2012). Teaching professionals and masters of mosaic - Work cultures as the context of action of the teachers in universities of applied sciences. PhD dissertation, Jyväskylä Studies in Business and Economics 109, University of Jyväskylä. English abstract.

Ministry of Education and Culture (2016). Retrieved from http://www.minedu.fi/export/sites/default/OPM/Koulutus/koulutusjaerjestelmae/liitteet/finnis $\underline{\text { h_education.pdf }}$

Paakkari, L., Tynjälä, P., Torppa, M., Villberg, J., \& Kannas, L. (2015). The development and alignment of pedagogical conceptions of health education. Teaching and Teacher Education, 49, 11-21.

Parpala, A. (2007). University teachers' conceptions of good teaching in the units of highquality education. Studies in Educational Evaluation, 33(3), 355-370.

Postareff, L., \& Lindblom Ylänne, S. (2008). Variation in teachers' descriptions of teaching: Broadening the understanding of teaching in higher education. Learning and Instruction, $18(2), 109-120$.

Prosser, M., \& Trigwell, K. (1997). Relations between perceptions of the teaching environment and approaches to teaching. British Journal of Educational Psychology, 67, $25-35$.

Prosser, M., \& Trigwell, K. (1999). Understanding learning and teaching: The Experience in Higher Education. The Society for Research into Higher Education. Oxfordshire, UK: Marston Lindsay Ross International Ltd.

Savonmäki, P. (2007). Collegial collaboration among teachers in polytechnic: A micropolitical perspective on teachership. PhD dissertation, University of Jyväskylä. Institute for Educational Research. Research Reports 23. English abstract.

Stes, A., \& van Petegem, P. (2011). Instructional development for early career academics: An overview of impact. Educational Research, 53(4), 459-474.

Stes, $\Lambda .$, \& van Petegem, P. (2014). Profiling approaches to teaching in higher education: A eluster analytic study. Studies in Higher Education, 39(4), 644658.

Trigwell, K., \& Prosser, M. (1996). Changing approaches to teaching: A relational perspective. Studies in Higher Education, 21, 275-284.

Van Eekelen, I. M., Boshuizen, H. P. A., \& Vermunt, J. D. (2005). Self-regulation in higher education teacher learning. Higher Education, 50(3), 447-471. 